\title{
Factors involved in the cisplatin resistance of KCP-4 human epidermoid carcinoma cells
}

\author{
SHIGERU OISO $^{1}$, YUI TAKAYAMA ${ }^{1}$, RIE NAKAZAKI ${ }^{1}$, NAOKO MATSUNAGA ${ }^{1}$, CHIE MOTOOKA $^{1}$, \\ ASUKA YAMAMURA ${ }^{1}$, RYUJI IKEDA ${ }^{2}$, KAZUO NAKAMURA ${ }^{3}$, \\ YASUO TAKEDA ${ }^{2}$ and HIROKO KARIYAZONO ${ }^{1}$ \\ ${ }^{1}$ Department of Pharmaceutical Health Care Sciences, Faculty of Pharmaceutical Sciences, \\ Nagasaki International University, Nagasaki 859-3298; ${ }^{2}$ Department of Clinical Pharmacy and Pharmacology, \\ Graduate School of Medical and Dental Sciences, Kagoshima University, Kagoshima 890-8520; \\ ${ }^{3}$ Department of Biopharmaceutics, Nihon Pharmaceutical University, Saitama 362-0806, Japan
}

Received September 24, 2013; Accepted November 11, 2013

DOI: $10.3892 /$ or.2013.2896

\begin{abstract}
KCP-4 is a cisplatin-resistant cell line established from human epidermoid carcinoma KB-3-1 cells. Although our previous study revealed that one of the mechanisms for cisplatin resistance in $\mathrm{KCP}-4$ cells is the activation of $\mathrm{NF}-\kappa \mathrm{B}$, its high resistance is considered to be induced by multiple mechanisms. In the present study, we explored other factors involved in the development of cisplatin resistance in KCP-4 cells. Since it has been reported that an unknown efflux pump exports cisplatin from KCP-4 cells in an ATP-dependent manner, we examined 48 types of ATP-binding cassette proteins as candidate cisplatin efflux transporters. The mRNA expression levels of $A B C A 1, A B C A 3, A B C A 7$ and $A B C B 10$ in $\mathrm{KCP}-4$ cells were higher when compared to those in KB-3-1 cells. These expression levels in cisplatin-sensitive revertant $\mathrm{KCP}-4$ cells (KCP-4R cells), were reduced in parallel with the sensitivity of these cells to cisplatin and their intracellular accumulation of cisplatin. Next, we investigated the occurrence of mutations in p53 in KCP-4 cells. We found a heterozygous missense mutation at codon 72 (p.Pro72Arg) in p53 of both KCP-4 and KB-3-1 cells, but the protein expression level of $\mathrm{p} 53$ in $\mathrm{KCP}-4$ cells was higher when compared to that in KB-3-1. These results suggest that $A B C A 1, A B C A 3$, $A B C A 7$ and $A B C B 10$ are candidate genes for the cisplatin efflux transporter that is involved in the cisplatin resistance of KCP-4 cells, and that the mutation at codon 72 of p53 may contribute to the development of cisplatin resistance.
\end{abstract}

Correspondence to: Professor Hiroko Kariyazono, Department of Pharmaceutical Health Care Sciences, Faculty of Pharmaceutical Sciences, Nagasaki International University, 2825-7 Huis Ten Bosch, Sasebo, Nagasaki 859-3298, Japan

E-mail: karihiro@niu.ac.jp

Key words: $A B C A 1, A B C A 3, A B C A 7, A B C B 10$, mutation, p53

\section{Introduction}

Cis-diamminedichloroplatinum II (cisplatin) is one of the most potent antitumor agents and has clinical activity against a wide variety of solid tumors, such as ovary, lung, head and neck, and bladder cancer (1-5). It is generally accepted that the cytotoxic activity of cisplatin results from its interactions with DNA, inhibition of DNA replication and DNA repair, disturbance of the cell cycle and the beneficial process of apoptosis in cancer therapy (6-8). However, resistance to cisplatin sometimes becomes a limiting factor in cisplatin-based chemotherapy (9-12). The mechanisms of resistance include accelerated DNA repair, inactivation of cisplatin by glutathione, altered apoptosis-related signals, activation of signaling pathways and declined accumulation of cisplatin due to decreased uptake and/or increased efflux (11-14).

With regard to the decline in the accumulation of cisplatin, it is known that the copper transporter 1 (CTR1) contributes to cisplatin uptake and regulates sensitivity to cisplatin $(15,16)$. The copper efflux transporter ATP7B has been reported to export cisplatin and its overexpression contributes to clinical cisplatin resistance $(17,18)$. Additionally, it has been suggested that the ATP-binding cassette (ABC) transporters MDR1, MRP1 and MRP2 may play a role in enhanced cisplatin efflux and cisplatin resistance $(14,19,20)$.

$\mathrm{KCP}-4$ is a highly cisplatin-resistant cell line derived from the human epidermoid carcinoma cell line KB-3-1 $(21,22)$. We previously investigated the resistance mechanisms of KCP-4 cells and reported that one of the mechanisms underlying cisplatin resistance in KCP-4 cells involves activation of $\mathrm{NF}-\kappa \mathrm{B}$ (23). In contrast, the accumulation of cisplatin was markedly reduced in KCP-4 cells when compared with the parent KB-3-1 cells. The time-dependent cisplatin accumulation in KCP-4 cells in response to the addition of cisplatin to the culture medium decreased rapidly, after an initial transient increase. This accumulation was enhanced by 2,4-dinitrophenol, an inhibitor of phosphorylation of ADP to ATP $(21,22,24)$. Therefore, it has been proposed that an ATP-dependent cisplatin efflux system exists in KCP-4 cells. However, ABC transporters, namely, MDR1,MRP1 and MRP2, 
were not expressed in KCP-4 cells $(24,25)$. Furthermore, ATP-dependent transport of leukotriene $\mathrm{C}_{4}\left(\mathrm{LTC}_{4}\right)$, an endogenous substrate for the glutathione $\mathrm{S}$-conjugate export pump (GS-X pump), has been found in membrane vesicles prepared from KCP-4 cells $(21,25)$. LTC $_{4}$ transport was inhibited by a GS-platinum complex and by cisplatin or glutathione, but it was not significant. These results suggested that the GS-X pump is involved in reducing the accumulation of cisplatin in $\mathrm{KCP}-4$ cells (25), but, to date, no GS-X pump has been found to be expressed in $\mathrm{KCP}-4$ cells.

The tumor suppressor p53, a transcription factor, inhibits tumor growth through the induction of apoptosis by activation of its target genes $(26,27)$. The p53 mutation has been found in approximately half of all types of cancer from a variety of tissues (28) and p53 is thought to be an important factor in the initiation and promotion of various types of cancer. It is known that p53 mutation enhances cisplatin resistance $(9,14,27)$. Exposure of cells to cisplatin activates several genes that mediate the activation of wild-type p53 and induces cell cycle arrest, DNA repair and apoptosis. When mutated, the apoptotic function of p53 is abrogated; the mutated protein cannot activate the cell death program and the sensitivity to cisplatin is reduced by disruption of the normal signal transduction pathways (9). Thus, the presence of mutations in p53 is an important factor for the development of cisplatin resistance. However, the characteristics of p53 in KCP-4 cells are also unclear.

The aim of the present study was to identify the factors involved in the cisplatin resistance of $\mathrm{KCP}-4$ cells. We demonstrated that mRNA expressions of $A B C A 1, A B C A 3, A B C A 7$ and $A B C B 10$ were increased in KCP-4 cells when compared with those in KB-3-1 cells; moreover, we found that there was a heterozygous missense mutation in the p53-encoding gene of KB-3-1 and KCP-4 cells.

\section{Materials and methods}

Cell culture. Dulbecco's modified Eagle's medium (DMEM) was purchased from Invitrogen Life Technologies (Carlsbad, CA, USA). KB-3-1, KCP-4 and cisplatin-sensitive revertant KCP-4R cells were established by Fujii et al (22) and Akiyama et al (29). All cells were cultured in DMEM containing $10 \%$ fetal bovine serum and $100 \mathrm{U} / \mathrm{ml}$ of penicillin (Invitrogen Life Technologies) at $37^{\circ} \mathrm{C}$ in a $5 \% \mathrm{CO}_{2}$ humidified atmosphere.

MTT assay. The 3-(4,5-dimethylthiazol-2-yl)-2,5-diphenyltetrazolium bromide (MTT) was purchased from Wako (Osaka, Japan). Cisplatin was purchased from Sigma (St. Louis, MO, USA). The MTT colorimetric assay was used to determine the relative sensitivity of cell lines to cisplatin, as previously reported (23). Briefly, KB-3-1, KCP-4 and KCP-4R cells were seeded in each well of 96 -well plates at $3 \times 10^{3}, 1 \times 10^{4}$ and $3 \times 10^{3}$ cells/200- $\mu 1 /$ well, respectively, and cultured for $24 \mathrm{~h}$. After a further $48 \mathrm{~h}$ in culture with cisplatin, $50 \mu \mathrm{l}$ of MTT solution $(1 \mathrm{mg} / \mathrm{ml}$ in PBS) was added to each well and culturing continued for $4 \mathrm{~h}$. The resultant formazan was dissolved with $100 \mu \mathrm{l}$ of dimethyl sulfoxide after aspiration of the culture medium; its absorbance at $595 \mathrm{~nm}$ was determined using a microplate reader.
Cisplatin accumulation. Cisplatin accumulation was assessed by the intracellular concentrations of platinum determined by inductive coupled plasma spectrometry (ICP). KB-3-1, KCP-4 and $\mathrm{KCP}-4 \mathrm{R}$ cells were cultured with cisplatin $(300 \mu \mathrm{mol} / \mathrm{l})$ for $2 \mathrm{~h}$ at $37^{\circ} \mathrm{C}$. Cells were washed 3 times with cold phosphate-buffered saline (PBS) and immediately harvested. The harvested cells were further washed with cold PBS and cell numbers were counted with a hemocytometer before the aspiration of PBS. Cell pellets were lysed in nitric acid and the concentrations of platinum were determined by ICP (23).

Reverse transcription-polymerase chain reaction ( $R T-P C R)$ analysis. Total RNA was extracted from KB-3-1, KCP-4 and $\mathrm{KCP}-4 \mathrm{R}$ cells using TRIzol (Invitrogen Life Technologies). Synthesis of first-strand cDNA was performed using the SuperScript III First-Strand Synthesis System (Invitrogen Life Technologies). PCR was performed using KOD-Plus(Toyobo, Tokyo, Japan). The reaction solutions were prepared in a final volume of $50 \mu \mathrm{l}$, containing $1 \mu \mathrm{l}$ of first-strand cDNA and $0.3 \mu \mathrm{mol} / 1$ sense and antisense primers. The PCR conditions included an initial denaturation step of 2 min at $94^{\circ} \mathrm{C}$, which was followed by 35 cycles of denaturation for $15 \mathrm{sec}$ at $94^{\circ} \mathrm{C}$, annealing for $30 \mathrm{sec}$ at $55-60^{\circ} \mathrm{C}$ and extension for $1 \mathrm{~min}$ at $68^{\circ} \mathrm{C}$.

Quantitative real-time $R T-P C R$ ( $q R T-P C R)$. The relative mRNA expression levels of $A B C A 1, A B C A 3, A B C A 7$ and $A B C B 10$ in the KB-3-1, KCP-4 and KCP-4R cells were evaluated by qRT-PCR using Fast SYBR-Green Master Mix (Life Technologies, Carlsbad, CA, USA) according to the manufacturer's instructions. To prepare the standard curve, $1 \mu \mathrm{g}$ of total RNA from KB-3-1, KCP-4, or KCP-4R cells was reverse transcribed with SuperScript III First-Strand Synthesis System, followed by the preparation of various cDNA dilutions. PCR, using an Applied Biosystems 7900HT Fast Real-Time PCR System (Life Technologies) apparatus, was performed in a final volume of $20 \mu \mathrm{l}$ of a reaction mixture composed of $10 \mu \mathrm{l}$ of $2 \mathrm{X}$ SYBR-Green PCR Master Mix, 0.4 pmol of the primers, and $2 \mu \mathrm{l}$ of diluted cDNA. The reaction mixture was then loaded onto a 386-well plate and subjected to an initial denaturation at $95^{\circ} \mathrm{C}$ for $20 \mathrm{sec}$, followed by 40 cycles of amplification at $95^{\circ} \mathrm{C}(2 \mathrm{sec})$ for denaturation, $60^{\circ} \mathrm{C}(20 \mathrm{sec})$ for annealing and extension. Primers used for qRT-PCR were: $A B C A 1$ sense, 5'-GGACCACTGCCCCAGTTCCC-3' and antisense, 5'-GGGGGACACACAGGCAGCAT-3'; ABCA3 sense, 5'-GC TGGTGGACAGCAGTATGG-3' and antisense, 5'-CTCCTC GATGAGGGCTCCAA-3'; ABCA7 sense, 5'-TACGGCAGAC GTCTTCAGCC-3' and antisense, 5'-TACTGGCCTGGGCA CACAGC-3'; and ABCB10 sense, 5'-TTGAGCGTGGTGCC TCCAGT-3' and antisense, 5'-GCTGAGTGGCTTGTGCCA GG-3'. The transcript amounts were estimated from the respective standard curves and normalized to $18 \mathrm{~S}$ ribosomal RNA (sense, 5'-GTAACCCGTTGAACCCCATT-3' and antisense, 5'-CCATCCAATCGGTAGTAGCG-3').

Immunoblot analysis. An antibody against p53 (DO-1) was obtained from Millipore (Billerica, MA, USA). Whole-cell lysates were prepared by lysing KB-3-1 and KCP-4 cells with detergent buffer $[10 \mathrm{mmol} / 1 \mathrm{Tris}-\mathrm{HCl}, \mathrm{pH} 7.5,5 \mathrm{mmol} / 1$ EDTA, $150 \mathrm{mmol} / 1$ sodium chloride, $1 \%$ Triton $\mathrm{X}-100$, 
$10 \%$ glycerol, 1X complete EDTA-free protease inhibitor cocktail (Roche Diagnostics, Indianapolis, IN, USA) and $1 \mathrm{mmol} / \mathrm{l}$ benzylsulfonyl fluoride]. Insoluble fractions were removed by centrifugation at $16,000 \mathrm{x}$ g for $10 \mathrm{~min}$ at $4^{\circ} \mathrm{C}$. Whole-cell lysates were then boiled in a quarter-volume of sample buffer $(125 \mathrm{mmol} / \mathrm{l}$ Tris- $\mathrm{HCl}, \mathrm{pH} 7.5,25 \%$ glycerol, $5 \%$ sodium dodecyl sulfate, $0.2 \%$ bromophenol blue and $25 \%$ 2-mercaptoethanol). Proteins in these samples were separated by SDS-PAGE (10\%) and transferred to a PVDF membrane (Bio-Rad Laboratories, Hercules, CA, USA). The membrane was incubated for $1 \mathrm{~h}$ in Tris-buffered saline (TBS) containing $5 \%$ non-fat milk as blocking buffer and then treated overnight with 1:1,000 anti-p53 antibodies in blocking buffer at $4^{\circ} \mathrm{C}$. The membrane was washed in TBS and then incubated with 1:3,000 HRP-conjugated goat anti-mouse IgG antibody (Nacalai Tesque, Inc., Kyoto, Japan) in blocking buffer at room temperature for $1 \mathrm{~h}$. It was then washed again in TBS. Antibody binding was visualized using the ECL Plus Western Blotting Detection System (GE Healthcare Bio-Sciences, Buckingham, UK).

Sequence analysis of p53 gene in KB-3-1 and KCP-4. Complementary DNA samples from total RNAs of KB-3-1 and KCP-4 amplified by RT-PCR were used as templates in the cycle sequence reaction. Primers used for amplification by RT-PCR were: sense, 5'-GTGACACGCTTCCCTGGATT-3' and antisense, 5'-GCTGTCAGTGGGGAACAAGA-3'. Cycle sequence reactions were performed using a BigDye Terminator v3.1 Cycle Sequencing kit (Life Technologies). Sequence primers were: 5'-GTGACACGCTTCCCTGGATT-3' and 5'-AGTTCCTGCATGGGCGGCAT-3'. The reactions were cycled at $96^{\circ} \mathrm{C}$ for $60 \mathrm{sec}$, followed by 25 cycles at $96^{\circ} \mathrm{C}$ for $10 \mathrm{sec}, 50^{\circ} \mathrm{C}$ for $5 \mathrm{sec}$ and $60^{\circ} \mathrm{C}$ for $4 \mathrm{~min}$. After purification, products were subjected to automated sequencing by capillary electrophoresis on an ABI3130 Genetic Analyzer (Life Technologies).

Statistical analysis. Differences between groups were tested by one-way ANOVA followed by Tukey's test for multiple comparisons. Data are presented as the means \pm SD. Differences were considered statistically significant at $\mathrm{P}<0.05$.

\section{Results}

Comparison of cisplatin resistance among $K B-3-1, K C P-4$ and $K C P-4 R$ cells. The cell viability of $\mathrm{KCP}-4$ cells in cisplatin-containing medium, as determined by the MTT assay, was compared with that of KB-3-1 and KCP-4R, which are a parental cell line and a cisplatin-sensitive revertant cell line of KCP-4, respectively (Fig. 1A). KCP-4 cells were considerably more resistant to cisplatin than the parental KB-3-1 cells. Sensitivity of KCP-4R cells to cisplatin was intermediate between that of KCP-4 and KB-3-1 cells. $\mathrm{EC}_{50}$ values of KB-3-1, KCP-4R and KCP-4 cells were $0.3,3$ and $>300 \mu \mathrm{mol} / 1$, respectively. Subsequently, the intracellular accumulation level of platinum in each cell line was measured. Platinum levels of KCP-4 cells were much lower than those of KB-3-1 cells $\left(122 \pm 27\right.$ and $1,138 \pm 132 \mathrm{pmol} / 10^{6}$ cells respectively; Fig. 1B). The levels of KCP-4R cells were $708 \pm 50 \mathrm{pmol} / 10^{6}$ cells.

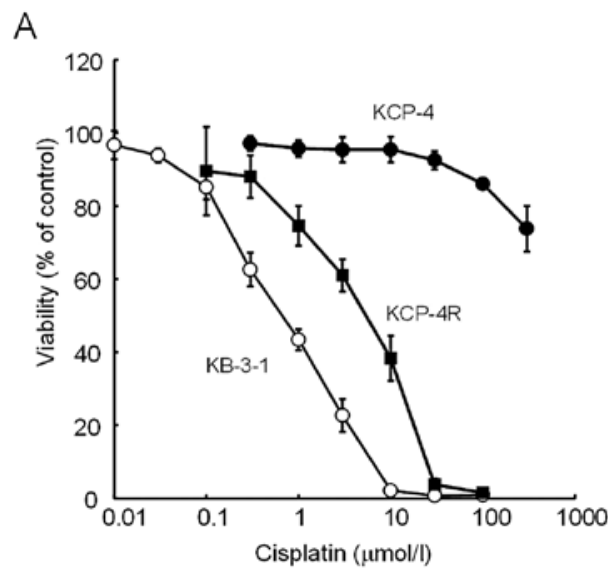

B

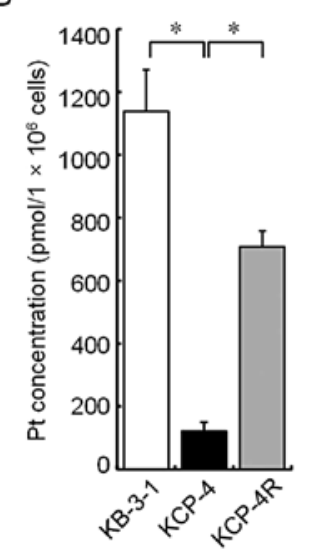

Figure 1. Comparison of sensitivity to cisplatin and intracellular accumulation of cisplatin in KB-3-1, KCP-4 and KCP-4 cells. (A) Sensitivity of KB-3-1, KCP-4 and KCP-4R cells to cisplatin. Viability after a 48-h culture in cisplatin-containing medium was determined by MTT assay. Data, expressed as a percentage of the control, represent the means \pm SD of 6 independent experiments. (B) The intracellular accumulation level of cisplatin in KB-3-1, KCP-4 and KCP-4R cells. Cisplatin accumulation was assessed by the intracellular concentrations of platinum determined by ICP. These data are expressed as the means \pm SD of 6 independent experiments. ${ }^{*} \mathrm{P}<0.01$. ICP, inductive coupled plasma spectrometry.

Messenger RNA expression of $A B C$ protein in $K B-3-1$ and $K C P-4$ cells. Previous studies suggested that an ATP-dependent cisplatin efflux system exists in KCP-4 cells $(21,22,24)$. It is well known that several $\mathrm{ABC}$ proteins function as an ATP-dependent efflux pump. We therefore investigated the mRNA expression of all $48 \mathrm{ABC}$ protein-encoding genes, including $A B C A s, A B C B s, A B C C s, A B C D s, A B C E s, A B C F s$, and $A B C G s$ in KCP-4 and KB-3-1 cells (Table I). RT-PCR analysis indicated increased mRNA expression of $A B C A 1$, $A B C A 3, A B C A 7$ and $A B C B 10$ in KCP-4 cells (Fig. 2).

Expression of $A B C A 1, A B C A 3, A B C A 7$ and $A B C B 10 \mathrm{mRNA}$ in $K C P-4 R$ cells. We then investigated the mRNA expression of $A B C A 1, A B C A 3, A B C A 7$ and $A B C B 10$ in KCP-4R cells by RT-PCR. We found that mRNA expressions of these 4 genes were reduced in $\mathrm{KCP}-4 \mathrm{R}$ cells when compared with those in $\mathrm{KCP}-4$ cells (Fig. 3A). qRT-PCR analysis revealed that the expression levels of $A B C A 1, A B C A 3, A B C A 7$ and $A B C B 10$ mRNA in KCP-4 cells were 77.2 $\pm 14.5-, 7.5 \pm 1.9-, 11.5 \pm 1.7-$ and 9.9 \pm 0.8 -fold higher, respectively, than those in KB-3-1 cells. 
Table I. RT-PCR primer sequences for amplifying ABC protein-encoding genes.

\begin{tabular}{|c|c|c|c|}
\hline No. & Gene name & Forward primer $\left(5^{\prime}-3^{\prime}\right)$ & Reverse primer $\left(5^{\prime}-3^{\prime}\right)$ \\
\hline 1 & $A B C A 1$ & gtcattatcatcttcatctgcttc & cctcacatcttcatcttcatcatt \\
\hline 2 & $A B C A 2$ & gcagccagagtgtgaaggacgtgg & gcagagcgtgtccgtgttgaagga \\
\hline 3 & $A B C A 3$ & gtgcaggccaagcatgtgcag & cagcaccaggaacacgtgatc \\
\hline 4 & $A B C A 4$ & aacgtcatcgtgagcatcatcaga & gaggtcatgactttcagtctgctg \\
\hline 5 & $A B C A 5$ & ggactggatagaaaacctagaagt & tactactctatcttcttgtgttcg \\
\hline 6 & $A B C A 6$ & ggcaaggattacattctagag & ggaggagtttccatctcattg \\
\hline 7 & $A B C A 7$ & atcgtggtgctcatctttctg & tggttccgcaccatgtcaatg \\
\hline 8 & $A B C A 8$ & ctcctaaccacccactacatg & tactcctctaggtcaaagctc \\
\hline 9 & $A B C A 9$ & accettctgcatactggtttg & tccatggaatcaggagaaatc \\
\hline 10 & $A B C A 10$ & aggaacgctaaggtgtattgg & ctcctgctctttacagagttc \\
\hline 11 & $A B C A 12$ & ctcacagcatggaagaatgtg & agagtggtctgactcactaag \\
\hline 12 & $A B C A 13$ & actgtggactggagacaatac & ggtacatccatggaagagttg \\
\hline 13 & $A B C B 1(M D R 1)$ & tacagcacggaaggcctaatg & tgttctcagcaatgctgcagt \\
\hline 14 & $A B C B 2$ & tggtctgttgactccettaca & aaatacctgtggctcttgtcc \\
\hline 15 & $A B C B 3$ & tacaacacccgccatcaggaa & tcataaaggaaagcaggctgc \\
\hline 16 & $A B C B 4$ & gaaacaagagtgggagataag & ctggacactgaccattgaaaa \\
\hline 17 & $A B C B 5$ & tgcagcattgctgagaacatc & actgactgtgcattcactaac \\
\hline 18 & $A B C B 6$ & tttcactgtgatgcctggaca & gatgcagccatccttgatgac \\
\hline 19 & $A B C B 7$ & tatgatgaagctacttcatcg & cgaacagtttccacagccttt \\
\hline 20 & $A B C B 8$ & ctggaagcttccgatgaagag & ttcaggagctcttcatgtgtc \\
\hline 21 & $A B C B 9$ & attgatggcatcgtcatccag & catgagaggctgaacatgaag \\
\hline 22 & $A B C B 10$ & ctgcttctggaactattagtc & actaacaccgttcttccatcc \\
\hline 23 & $A B C B 11$ & gtgttgtttgcctgtagcata & ccatgacagcaatgatatccg \\
\hline 24 & $A B C C 1(M R P 1)$ & gacacagtggactccatgatc & ccaccaagccagcactgaggc \\
\hline 25 & $A B C C 2(M R P 2)$ & gcagcgatttctgaaacacaa & tcaacagccacaatgttggtc \\
\hline 26 & $A B C C 3$ & acctgcacacgtttgtgagct & gaagatgcctctagctgcaat \\
\hline 27 & $A B C C 4$ & caaatgtggatccaagaactg & ggaagtgtttgtaaccatgtg \\
\hline 28 & $A B C C 5$ & ctagagagactgtggcaagaa & aaatgccatggttaggatggc \\
\hline 29 & ABCC6 & aagatccacgcaggagagaag & cagacacaggagctgtttctg \\
\hline 30 & $A B C C 7$ & cgaagatcttgctgcttgatg & tcttgcacctcttcttctgtc \\
\hline 31 & $A B C C 8$ & ctgagaggaagtgctcagata & tgagcagcttctctggcttat \\
\hline 32 & $A B C C 9$ & gcaggatccaatactattcag & aagagacacggtgagctattg \\
\hline 33 & $A B C C 10$ & tccctgttgttggtgctcttc & tctgagttcaggatcgtgttg \\
\hline 34 & $A B C C 11$ & tcccacatcctcaattctctg & tgtgccttccatgtgtaaagg \\
\hline 35 & $A B C C 12$ & gagagaacattcatgagagac & cttctgctgctagtaacatcg \\
\hline 36 & $A B C D 1$ & actcagtggaggacatgcaaa & cgaactgtagcaagtgtgtgt \\
\hline 37 & $A B C D 2$ & atgctgttatggactggaaag & tccagctagctgagattctag \\
\hline 38 & $A B C D 3$ & ggaagggaatttctgacctag & catatgcaggtagtactcatg \\
\hline 39 & $A B C D 4$ & cgatgatgagaggatcttgag & ccacagagtttcagaaccaag \\
\hline 40 & $A B C E 1$ & tcacccacaatttgtgaccga & ggtttgaggactgtttgcaac \\
\hline 41 & $A B C F 1$ & gcttcttcaaccagcagtatg & agctggcaattggtttctgtg \\
\hline 42 & $A B C F 2$ & agctggacttagatctctcac & cacttggtgattgtctgcttc \\
\hline 43 & $A B C F 3$ & ccttcatcaagagtaagcagg & agactcgagatcagcagacac \\
\hline 44 & $A B C G 1$ & ttcagatcatgttcccagtgg & gaggacaaaataggcaatgag \\
\hline 45 & $A B C G 2$ & tcaggaagacttatgttccac & agctctgttctggattccagt \\
\hline 46 & $A B C G 4$ & tatggctgagaagaagagcag & aaggtgagcacagttggcatg \\
\hline 47 & $A B C G 5$ & tagtcaacagtgtagtggctc & ctaggatgacaagagctggaa \\
\hline 48 & $A B C G 8$ & actgtgcctacatcatcatct & ctgctgaactgaatcttcatc \\
\hline 49 & $G A P D H$ & gtgtgaaccatgagaagtatg & tttggcaggtttttctagacg \\
\hline
\end{tabular}

ABC, ATP-binding cassette. 

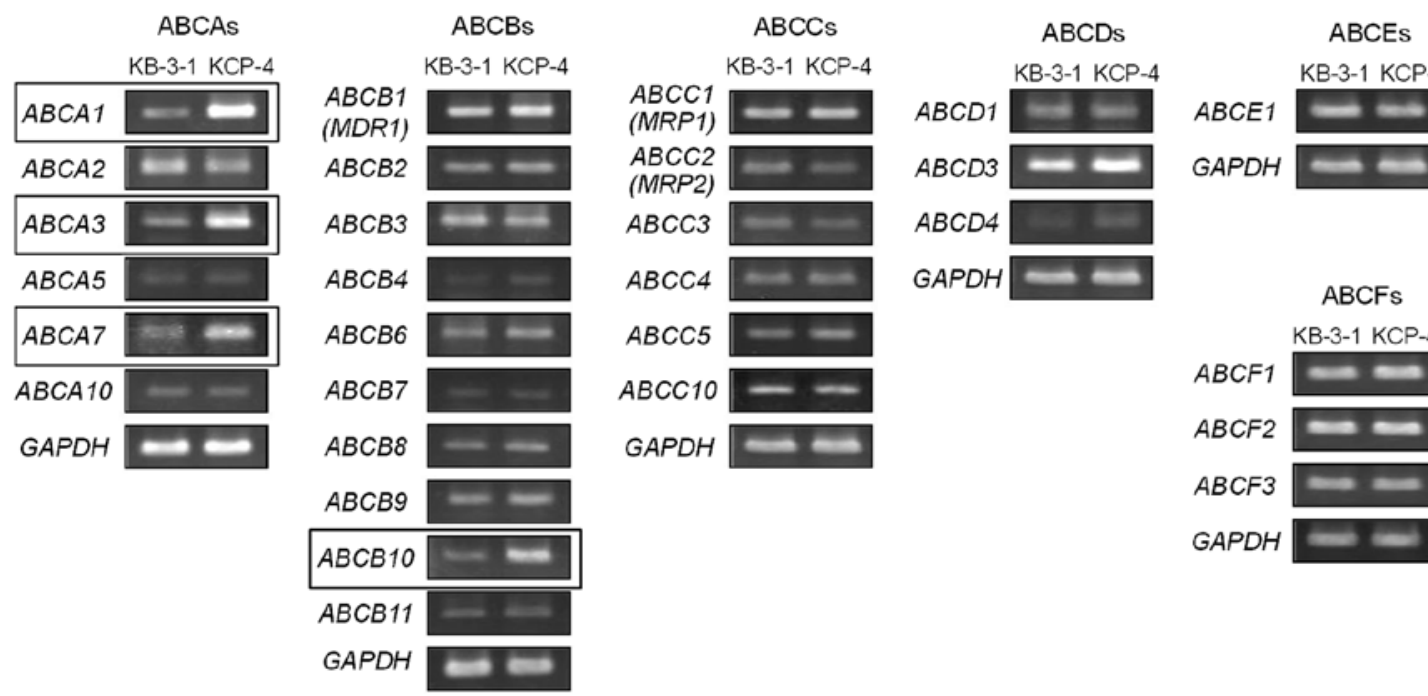

Figure 2. Messenger RNA expression of ATP-binding (ABC) protein-encoding genes in KB-3-1 and KCP-4 cells. (A) Messenger RNA expressions were detected by RT-PCR using specific primers for cDNA corresponding to each ABC protein cDNA (Table I). The data of ABC protein cDNAs for which no amplified signal was observed in either KB-3-1 and KCP-4 cells are not shown. Boxes indicate higher expression in KCP-4 cells when compared with those in KB-3-1 cells.

A

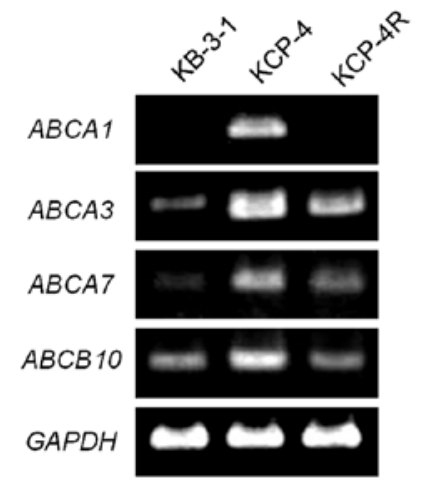

B

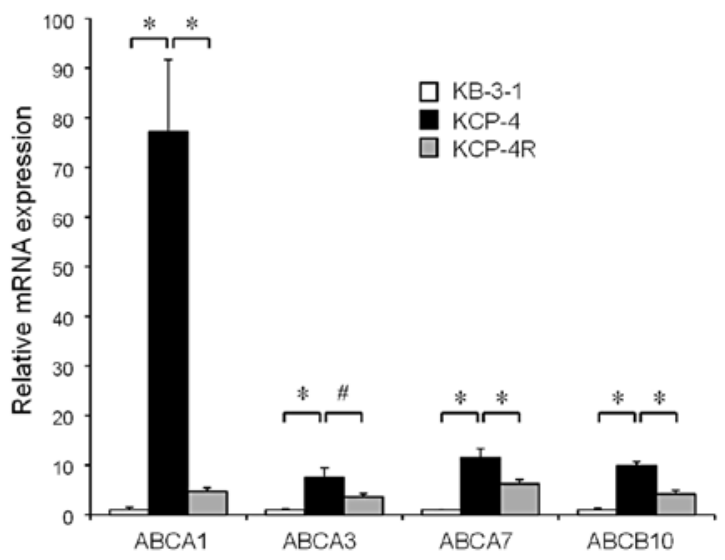

Figure 3. Comparison of mRNA expression levels of $A B C A 1, A B C A 3, A B C A 7$ and $A B C B 10$ in $\mathrm{KB}-3-1$, KCP-4 and KCP-4R cells. (A) Messenger RNA expression of $A B C A 1, A B C A 3, A B C A 7$ and $A B C B 10$ in KB-3-1, KCP-4 and KCP-4R cells as detected by RT-PCR. (B) Relative mRNA expression of $A B C A 1$, $A B C A 3, A B C A 7$ and $A B C B 10$ in KB-3-1, KCP-4 and KCP-4R cells, as determined by qRT-PCR. These data are expressed as the means \pm SD of 3 independent experiments. ${ }^{*} \mathrm{P}<0.01 ;{ }^{\#} \mathrm{P}<0.05$.

However, the levels in $\mathrm{KCP}-4 \mathrm{R}$ cells were significantly reduced when compared with those in KCP-4 cells (relative expression levels of KCP-4R vs. KCP-4 cells, 0.06 $\pm 0.01-, 0.45 \pm 0.09$-, 0.54 \pm 0.09 - and 0.42 \pm 0.09 -fold, respectively; Fig. 3B).

Expression of p53 in KB-3-1 and KCP-4 cells and sequence analysis. We also investigated whether p53 protein was expressed in KB-3-1 and KCP-4 cells by immunoblot analysis. The expression level of p53 in KCP-4 was higher than that in KB-3-1 (Fig. 4A). Sequence analyses of p53 genes prepared from KB-3-1 and KCP-4 cells revealed the existence of a common heterozygous mutation (c. $215 \mathrm{C}>\mathrm{G}$ ) in the p53-encoding gene of both cells (Fig. 4B). This missense mutation results in the substitution of proline at codon 72 for arginine (p.Pro72Arg).

\section{Discussion}

$\mathrm{KCP}-4$ is a cisplatin-resistant cell line derived from the human epidermoid carcinoma cell line KB-3-1. In the present study, we showed that the resistance of $\mathrm{KCP}-4$ cells to cisplatin was approximately 1,000-fold greater than that of KB-3-1 cells and that the accumulation of cisplatin in KCP-4 cells was markedly decreased when compared with that in KB-3-1 cells. Furthermore, the cisplatin sensitivity of the KCP-4R cell line, which represents revertant $\mathrm{KCP}-4$ cells, recovered to nearly the level of KB-3-1 cells and the accumulation of cisplatin in $\mathrm{KCP}-4 \mathrm{R}$ cells was markedly higher than that in KCP-4 cells. These results indicated that the cisplatin resistance of $\mathrm{KCP}-4$ cells is associated with the intracellular accumulation of cisplatin. Previous studies showed that the accumulation of 
A

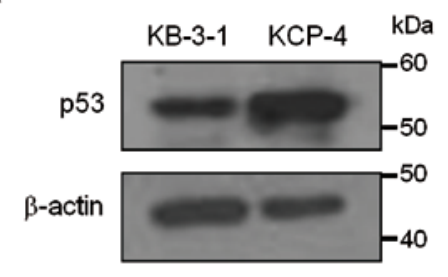

B
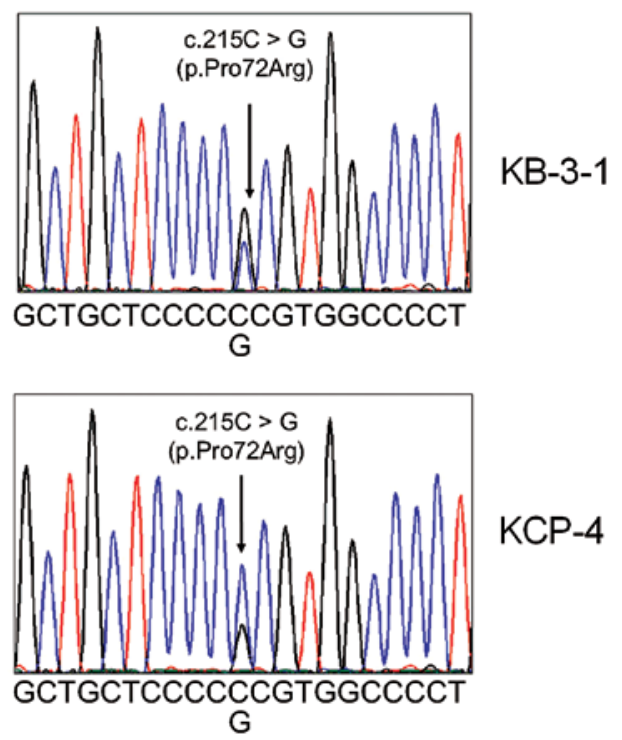

Figure 4. Immunoblot and sequence analyses for p53 in KB-3-1 and KCP-4 cells. (A) The expression of p53 in KB-3-1 and KCP-4 cells as detected by immunoblotting. (B) Sequence analysis of p53 cDNA from KB-3-1 and $\mathrm{KCP}-4$ cells. Both sequences indicate the existence of the same heterozygous mutation at codon 72 of p53.

cisplatin in KCP-4 cells was markedly decreased; this appeared to be mediated by any ATP-dependent efflux pump $(21,22,24)$. Although some studies have reported that overexpression of MDR1, MRP1 and MRP2 is related to the mechanism of cisplatin resistance $(14,19,20)$, other studies revealed that none of those were involved in the cisplatin resistance of KCP-4 cells $(24,25)$. Our data showed that mRNA expression levels of $M D R 1, M R P 1$ and $M R P 2$ in KCP-4 cells were not higher than those in KB-3-1 cells, which were consistent with the latter proposal $(24,25)$. In contrast, $A B C A 1, A B C A 3, A B C A 7$ and $A B C B 10$ were highly expressed in KCP-4 cells when compared with KB-3-1 cells. The expression levels of $A B C A 1$, $A B C A 3, A B C A 7$ and $A B C B 10$ in revertant KCP-4R cells were markedly reduced when compared with those in KCP-4 cells, but were not equal to those of KB-3-1 cells. Quantitative realtime RT-PCR analysis also showed similar variations.

The sensitivity of KCP-4R cells to cisplatin as determined by MTT assay and cisplatin accumulation levels in KCP-4R cells was also markedly, but not completely recovered, to the levels of KB-3-1 cells. The expression of $A B C A 1, A B C A 3$, $A B C A 7$ and $A B C B 10$ in KB-3-1, KCP-4 and KCP-4R cells varied in parallel with sensitivity to cisplatin and the intracellular accumulation level of cisplatin. These results suggested that $\mathrm{ABCA} 1, \mathrm{ABCA} 3, \mathrm{ABCA} 7$ and $\mathrm{ABCB} 10$ may contribute to the cisplatin resistance of KCP-4 cells.
ABCA1 plays a role in phospholipid transport, cholesterol homeostasis and high-density lipoprotein metabolism $(30,31)$. Previous studies showed that the expression of ABCA1 may be associated with resistance to an antitumor drug. The antitumor activity of nitidine, a benzophenanthridine alkaloid that has antitumor effects via the inhibition of topoisomerase I, was increased upon downregulation of ABCA1 (32). In addition, it was reported that $\mathrm{ABCA} 1$ may be related to the resistance to the antitumor activity of curcumin (33). Moreover, it was also reported that the grade of cancer is influenced by the cholesterol environment in prostate cancer and that ABCA1 expression contributes to the control of this environment $(34,35)$. However, ABCA1 has not been reported to be associated with resistance to cisplatin.

ABCA3 is known to be expressed predominantly at the limiting membrane of the lamellar bodies in lung alveolar type II cells and is involved in surfactant secretion $(36,37)$. Regarding antitumor drug resistance, ABCA 3 is reported to be involved in multidrug resistance of some leukemia cells $(38,39)$. These studies showed that ABCA3 remains localized within the limiting membranes of lysosomes and multivesicular bodies and induces a phenotype of broad multidrug resistance, mediated by subcellular drug sequestration to lysosomes. If ABCA3 is associated with the cisplatin resistance of KCP-4 cells in the same manner, the intracellular accumulation of cisplatin would be unchanged. However, our data indicated that accumulation of cisplatin in KCP-4 cells is markedly decreased when compared with that in KB-3-1 cells. Therefore, ABCA3 would not be associated with the cisplatin resistance of KCP-4 cells or would be involved via a different mechanism from that in multidrug-resistant leukemia cells.

ABCA7 is reported to be associated with phospholipid transport, similar to ABCA1 (40), and is linked to Alzheimer's disease $(41,42)$. However, to date, no report has demonstrated the association of ABCA7 with antitumor drug resistance.

$\mathrm{ABCB} 10$ has been identified as a mitochondrial transporter induced by GATA-1 during erythroid differentiation $(43,44)$. It is known that $\mathrm{ABCB} 10$ is involved in mitochondrial iron importation and heme biosynthesis by interacting with an iron importer, mitoferrin-1, in the mitochondrial membrane $(45,46)$. The association of $\mathrm{ABCB} 10$ with antitumor drug resistance has yet to be clarified.

A previous study showed that the cisplatin efflux pump in KCP-4 cells functions as a GS-X pump (25). Although MRP1 and MRP2, among ABC proteins, are already known to function as GS-X pumps (47), it is unknown whether ABCA1, ABCA3, ABCA7 and ABCB10 function as GS-X pumps. To clarify their potential function as GS-X pumps and the association of each candidate $\mathrm{ABC}$ protein to cisplatin resistance, further studies using a stable cell line that expresses high levels of each candidate $\mathrm{ABC}$ protein alone are required.

In the present study, we also investigated whether there were any mutations in the p53-encoding genes of KB-3-1 and KCP-4 cells. Sequence analyses demonstrated a common heterozygous mutation, which results in the substitution of proline at codon 72 for arginine in p53 of both cells. Bergamaschi et al (48) reported that head and neck cancer expressing a p53 mutant involving arginine at codon 72 (72R) had a lower response to chemotherapy than those expressing p53 with proline at codon 72 (72P). The expression level of p53 
protein in KCP-4 cells was also higher than that in KB-3-1, so that $72 \mathrm{R}$ may strongly influence the resistance of $\mathrm{KCP}-4$ to cisplatin.

In the present study, we showed that enhanced expression of $A B C A 1, A B C A 3, A B C A 7$ and $A B C B 10$ and the mutation of p53 at codon 72 , alone or in combinations, may be candidate factors of the cisplatin resistance mechanism of KCP-4 cells. We previously reported that one of the mechanisms for cisplatin resistance in KCP-4 cells is the activation of NF- $\kappa \mathrm{B}(23)$. $\mathrm{KCP}-4$ cells may be highly resistant to cisplatin due to multiple mechanisms, such as increased cisplatin efflux, expression of

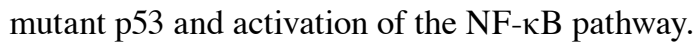

\section{Acknowledgements}

The authors thank Dr Shin-ichi Akiyama for providing KB-3-1, $\mathrm{KCP}-4$ and KCP-4R cells.

\section{References}

1. Loehrer PJ and Einhorn LH: Drugs five years later. Cisplatin. Ann Intern Med 100: 704-713, 1984.

2. Elit L, Oliver TK, Covens A, et al: Intraperitoneal chemotherapy in the first-line treatment of women with stage III epithelial ovarian cancer: a systematic review with metaanalyses. Cancer 109: 692-702, 2007

3. Sculier JP and Moro-Sibilot D: First- and second-line therapy for advanced nonsmall cell lung cancer. Eur Respir J 33: 915-930, 2009.

4. Vermorken JB and Specenier P: Optimal treatment for recurrent/metastatic head and neck cancer. Ann Oncol 21 (Suppl 7): vii252-261, 2010.

5. Ismaili N, Amzerin $\mathrm{M}$ and Flechon A: Chemotherapy in advanced bladder cancer: current status and future. J Hemato Oncol 4: 35, 2011

6. Comess KM, Burstyn JN, Essigmann JM and Lippard SJ: Replication inhibition and translesion synthesis on templates containing site-specifically placed cis-diamminedichloroplatinum(II) DNA adducts. Biochemistry 31: 3975-3990, 1992.

7. SuoZ,Lippard SJ and Johnson KA: Single d $(\mathrm{GpG}) /$ cis-diammineplatinum(II) adduct-induced inhibition of DNA polymerization. Biochemistry 38: 715-726, 1999.

8. Wang G, Reed E and Li QQ: Molecular basis of cellular response to cisplatin chemotherapy in non-small cell lung cancer (Review). Oncol Rep 12: 955-965, 2004.

9. Siddik ZH: Cisplatin: mode of cytotoxic action and molecular basis of resistance. Oncogene 22: 7265-7279, 2003.

10. Kelland LR: New platinum antitumor complexes. Crit Rev Oncol Hematol 15: 191-219, 1993.

11. Timmer-Bosscha H, Mulder NH and de Vries EG: Modulation of cis-diamminedichloroplatinum(II) resistance: a review. $\mathrm{Br} J$ Cancer 66: 227-238, 1992.

12. Borst P, Rottenberg S and Jonkers J: How do real tumors become resistant to cisplatin? Cell Cycle 7: 1353-1359, 2008.

13. Torigoe T, Izumi H, Ishiguchi H, et al: Cisplatin resistance and transcription factors. Curr Med Chem Anticancer Agents 5 : 15-27, 2005.

14. Stewart DJ: Mechanisms of resistance to cisplatin and carboplatin. Crit Rev Oncol Hematol 63: 12-31, 2007.

15. Safaei R and Howell SB: Copper transporters regulate the cellular pharmacology and sensitivity to Pt drugs. Crit Rev Oncol Hematol 53: 13-23, 2005.

16. Ishida S, Lee J, Thiele DJ and Herskowitz I: Uptake of the anticancer drug cisplatin mediated by the copper transporter Ctr1 in yeast and mammals. Proc Natl Acad Sci USA 99: 14298-14302, 2002.

17. Miyashita H, Nitta Y, Mori S, et al: Expression of coppertransporting P-type adenosine triphosphatase (ATP7B) as a chemoresistance marker in human oral squamous cell carcinoma treated with cisplatin. Oral Oncol 39: 157-162, 2003.

18. Samimi G, Safaei R, Katano K, et al: Increased expression of the copper efflux transporter ATP7A mediates resistance to cisplatin, carboplatin, and oxaliplatin in ovarian cancer cells. Clin Cancer Res 10: 4661-4669, 2004
19. Surowiak P, Materna V, Kaplenko I, et al: ABCC2 (MRP2, cMOAT) can be localized in the nuclear membrane of ovarian carcinomas and correlates with resistance to cisplatin and clinical outcome. Clin Cancer Res 12: 7149-7158, 2006.

20. Taniguchi K, Wada M, Kohno K, et al: A human canalicular multispecific organic anion transporter (cMOAT) gene is overexpressed in cisplatin-resistant human cancer cell lines with decreased drug accumulation. Cancer Res 56: 4124-4129, 1996.

21. Fujii R, Mutoh M, Sumizawa T, Chen ZS, Yoshimura A and Akiyama S: Adenosine triphosphate-dependent transport of leukotriene $\mathrm{C}_{4}$ by membrane vesicles prepared from cisplatin-resistant human epidermoid carcinoma tumor cells. J Natl Cancer Inst 86: 1781-1784, 1994.

22. Fujii R, Mutoh M, Niwa K, Yamada K, Aikou T, Nakagawa M, Kuwano $M$ and Akiyama S: Active efflux system for cisplatin in cisplatin-resistant human KB cells. Jpn J Cancer Res 85: 426-433, 1994.

23. Oiso S, Ikeda R, Nakamura K, Takeda $Y$, Akiyama $S$ and Kariyazono $\mathrm{H}$ : Involvement of $\mathrm{NF}-\kappa \mathrm{B}$ activation in the cisplatin resistance of human epidermoid carcinoma KCP-4 cells. Oncol Rep 28: 27-32, 2012.

24. Chen ZS, Mutoh M, Sumizawa T, et al: An active efflux system for heavy metals in cisplatin-resistant human KB carcinoma cells. Exp Cell Res 240: 312-320, 1998.

25. Chuman Y, Chen ZS, Sumizawa T, et al: Characterization of the ATP-dependent $\mathrm{LTC}_{4}$ transporter in cisplatin-resistant human KB cells. Biochem Biophys Res Commun 226: 158-165, 1996.

26. Velculescu VE and El-Deiry WS: Biological and clinical importance of the $p 53$ tumor-suppressor gene. Clin Chem 42: 858-868, 1996.

27. El-Deiry WS: The role of p53 in chemosensitivity and radiosensitivity. Oncogene 22: 7486-7495, 2003.

28. Hussain SP and Harris CC: Molecular epidemiology of human cancer: contribution of mutation spectra studies of tumor suppressor genes. Cancer Res 58: 4023-4037, 1998.

29. Akiyama S, Fojo A, Hanover JA, Pastan I and Gottesman MM: Isolation and genetic characterization of human KB cell lines resistant to multiple drugs. Somat Cell Mol Genet 11: 117-126, 1985.

30. Tanaka AR, Abe-Dohmae S, Ohnishi T, et al: Effects of mutations of ABCA1 in the first extracellular domain on subcellular trafficking and ATP binding/hydrolysis. J Biol Chem 278: $8815-8819,2003$

31. Nagao K, Takahashi K, Hanada K, Kioka N, Matsuo M and Ueda K: Enhanced apoA-I-dependent cholesterol efflux by ABCA1 from sphingomyelin-deficient Chinese hamster ovary cells. J Biol Chem 282: 14868-14874, 2007.

32. Iwasaki H, Okabe T, Takara K, Yoshida Y, Hanashiro K and Oku H: Down-regulation of lipids transporter ABCA1 increases the cytotoxicity of nitidine. Cancer Chemother Pharmacol 66: 953-959, 2010.

33. Bachmeier BE, Iancu CM, Killian PH, et al: Overexpression of the ATP binding cassette gene ABCA1 determines resistance to Curcumin in M14 melanoma cells. Mol Cancer 8: 129, 2009.

34. Lee BH, Taylor MG, Robinet P, et al: Dysregulation of cholesterol homeostasis in human prostate cancer through loss of $A B C A 1$. Cancer Res 73: 1211-1218, 2013.

35. Sekine Y, Demosky SJ, Stonik JA, et al: High-density lipoprotein induces proliferation and migration of human prostate androgenindependent cancer cells by an ABCA1-dependent mechanism. Mol Cancer Res 8: 1284-1294, 2010.

36. Matsumura Y, Sakai H, Sasaki M, Ban N and Inagaki N: ABCA3mediated choline-phospholipids uptake into intracellular vesicles in A549 cells. FEBS Lett 581: 3139-3144, 2007.

37. Matsumura Y, Ban N, Ueda K and Inagaki N: Characterization and classification of ATP-binding cassette transporter ABCA3 mutants in fatal surfactant deficiency. J Biol Chem 281: 34503-34514, 2006.

38. Chapuy B, Koch R, Radunski U, et al: Intracellular ABC transporter A3 confers multidrug resistance in leukemia cells by lysosomal drug sequestration. Leukemia 22: 1576-1586, 2008.

39. Chapuy B, Panse M, Radunski U, et al: ABC transporter A3 facilitates lysosomal sequestration of imatinib and modulates susceptibility of chronic myeloid leukemia cell lines to this drug. Haematologica 94: 1528-1536, 2009.

40. Iwamoto N, Abe-Dohmae S, Sato R and Yokoyama S: ABCA7 expression is regulated by cellular cholesterol through the SREBP2 pathway and associated with phagocytosis. J Lipid Res 47: 1915-1927, 2006.

41. Karch CM, Jeng AT, Nowotny P, Cady J, Cruchaga C and Goate AM: Expression of novel Alzheimer's disease risk genes in control and Alzheimer's disease brains. PLoS One 7: e50976, 2012. 
42. Kim WS, Li H, Ruberu K, et al: Deletion of Abca7 increases cerebral amyloid- $\beta$ accumulation in the J20 mouse model of Alzheimer's disease. J Neurosci 33: 4387-4394, 2013.

43. Graf SA, Haigh SE, Corson ED and Shirihai OS: Targeting, import, and dimerization of a mammalian mitochondrial ATP binding cassette (ABC) transporter, ABCB10 (ABC-me). J Biol Chem 279: 42954-42963, 2004.

44. Shirihai OS, Gregory T, Yu C, Orkin SH and Weiss MJ: ABC-me: a novel mitochondrial transporter induced by GATA-1 during erythroid differentiation. EMBO J 19: 2492-2502, 2000.

45. Chen W, Dailey HA and Paw BH: Ferrochelatase forms an oligomeric complex with mitoferrin-1 and Abcb10 for erythroid heme biosynthesis. Blood 116: 628-630, 2010
46. Chen W, Paradkar PN, Li L, et al: Abcb10 physically interacts with mitoferrin-1 (Slc25a37) to enhance its stability and function in the erythroid mitochondria. Proc Natl Acad Sci USA 106: 16263-16268, 2009.

47. Ishikawa T, Li ZS, Lu YP and Rea PA: The GS-X pump in plant, yeast, and animal cells: structure, function, and gene expression. Biosci Rep 17: 189-207, 1997.

48. Bergamaschi D, Gasco M, Hiller L, et al: p53 polymorphism influences response in cancer chemotherapy via modulation of p73-dependent apoptosis. Cancer Cell 3: 387-402, 2003. 